\title{
The concept of human personality al-Ghazali and sigmund freud in counseling perspectives
}

\author{
Andi Thahir ${ }^{1}$, Riyan Hidayat ${ }^{2}$ \\ Universitas Islam Negeri Raden Intan Lampung \\ andithahir@radenintan.ac.id
}

Submitted : 2020-04-27, Revised : 2020-05-14, Accepted : 2020-05-28

\begin{abstract}
The counseling perspective has a role in providing a personality description that feels needs attention in counseling. Personality, according to two figures in the science of counseling, the concept of personality formulated by Al-Ghazali and Sigmund Freud has suitability as well as facilitating or contributing personality theories to counseling that makes justification when the counseling process. The design of this study is an analytic design aimed at testing hypotheses and carrying out a more in-depth interpretation of a relationship of conformity in content and data. The difference in human concepts, according to Al-Ghazali and Sigmund Freud, lies in the workings of the three terms of human personality. Al-Ghazali explained that the dimension of the nafs is a level that has the potential that every human being will be in it. Whereas the concept of the structure of the human personality that has been explained according to Freud, that is, the three systems are interrelated and controlled by the ego as a controller for deciding a human behavior and personality.
\end{abstract}

Keywords: Al-Ghazali Perspectives; Human Personality; Sigmund Freud Perspectives

\section{Introduction}

Human concepts occupy a central point in the system of thought. Collingwood asserts that human nature is a knowing subject. Therefore, the concept of humanity is essential as a condition of critical justification and an absolute basis for specialized knowledge. Psychology as a discipline that studies humans integrally has a long history in its development starting around 1879(Valsiner, Chaudhary, \& Benetka, 2017). Then from the Islamic figure is Abu Ali Muhammad al-Hassan or Ibn Haitham alias Alhazen. Through his book, the Book of Optics has applied experimental psychology. Besides, the concept of human personality is of particular concern to thinkers and scientists. Thus, the formulation of meaning from the human figure arises. Character is a dynamic organization within the individual of the psychophysical system that determines its unique adaptation to its environment (Međedović, 2018). However, this research accent is about the concept of human personality from two figures, namely, Al-Ghazali and Sigmund Freud.

Al-Ghazali was a great Islamic thinker who lived in 1058-1111 AD He had extensive knowledge, his virtues as a scholar, theologian, philosopher, and leading critic and was able to inspire scientists after his death, such as Al-Thus, Ibn Rushd, Ibn Taymiyah, Ibn Khaldun and others (Booth, 2017). Al-Ghazali has succeeded in creating a religious balance in Muslims that is unmatched in human history. In looking at humans, Al-Ghazali, in his work in the fields of philosophy and Sufism, states humans can be understood through his soul; the soul is a permanent human identity. The human soul is a substantial immaterial that stands alone, does not consist of the elements that make it up so that it is eternal and not destroyed (Campanini, 2018).

Al-Ghazali discusses human essence, namely, qalb, spirit, nafs, and aql. However, in the heart of humanity, researchers will more specifically investigate al-Nafs which is the identity of the human personality, or better known as al-Nafs Al-Insaniyah (Human Soul) (Yahya et al., 2018). Al-Ghazali divides three levels, namely, al-Nafs Ammarah, al-Nafs Lawwamah, and al-Nafs Muthmai'inah. The three levels of the human soul are: Al-Nafs Ammarah is a basic urge on humans to fulfill what they want, which gathers strength, anger, and lust for humans. Al-Nafs Lawwamah compromises the drive for self-satisfaction or desire for norms and, at the same time, as opponents. Because he (nafs) will oppose the attitude of its owner, especially when he (the servant) fails to worship his Rabb. Al-Nafs 
Muthma'innah is a nafs that is in a calm condition that follows norms and values and is under control (self), and does not shake or does not fluctuate, so it is more because of resistance to lust, called nafs al-muthma'innah (calm soul).

The use of these three terms shows that his view of the essence or concept of the human soul is profound. Furthermore, the concept of human personality from one of the significant figures of Western scientists, the father of psychoanalysis, is Sigmund Freud. Sigmund Freud occupies an essential record as a scientist who influenced the 20th century because of his thinking, especially about human concepts. Sigmund Freud's thoughts about humans were greatly influenced by the 19th-century philosophy of determinism and positivism(Mandelbaum, 2019). He considers that human organisms as complex energy systems that obtain energy from food and use it for the human activity itself. Occurred from a consistent view of humans to be the starting point for the birth of theories about the structure of human personality as the essence or nature of human beings. Analysis of the formulation of terms from these names, Id (das Es), Ego (das Ich), and Superego (das Uberich)(Jones, 2019).

Sigmund Freud gave an understanding of these three terms. Namely, Id (das Es) is the oldest aspect of personality, the first personality system, existed from birth (maybe even before birth), genetically inherited, directly related to human biological impulses, and as a source/reserve of energy humans, so that it is expressed as a bridge between human biological and psychological aspects. Id work based on first principles so that they are chaotic (chaotic, without rules), do not know morals, do not have a sense of right and wrong. The only thing that is identified by the id is that the feeling of pleasure is not happy, so it is said that the id works according to the Pleasure Principle. The ego (das Ich) is the "me" or "self" that grew out of id when I was a baby. In terms of personality, it can distinguish between fantasy and reality and be a source for communicating with the outside world. With ego, individuals can identify themselves from the surrounding environment so that it forms the core that integrates personality. The ego arises because the needs of the organism require transactions that are by objective reality, so it is said that the ego works on the principle of truth (the Principle of Reality). Super Ego (das Uber Ich) is the moral or ethical part of the personality that internalizes social and moral norms. So that it becomes an internal manifestation of traditional values and ideals of society, as explained by parents to children and implemented by giving them gifts or punishment. And, superego's work is controlled by moral principles (Starkstein, 2018).

In concluding the description of the three-component systems, it must be remembered that the id, ego, and superego are not seen as carrying personality. All three are names for various psychological processes that follow the principles of different systems. However, in ordinary circumstances, the laws of birth are not in conflict with each other. Instead, they work together like a team that is controlled by the ego. The function of the human personality as a whole, not as three separate components (Niaz, Stanikzai, \& Sahibzada, 2019). Accurately, the three components of personality are interpreted as; Id is a biological aspect, the ego represents a psychological aspect, and the superego is the sociological aspect of human personality. In brief, it can be seen that Al-Ghazali and Sigmund Freud have differences in the concept of human personality. Al-Ghazali views humans as more comprehensive and substantive. According to him, looking at humans must be inclusive, starting from the material structure, to immaterial, so that the actual human form is visible. Whereas Sigmund Freud views his concept of personality only from the dominant aspect of heredity so that it will be formed from the human personality itself.

At this point, the difference in seeing the human personality is evident. Starting with a different era background, then a different belief. Besides what makes it even more interesting, Sigmund Freud claims to be an atheist. This is in line with his statement that religious 
doctrine is an illusion; religion carries the consequences of the incompatibility of human instincts with the reality of the world (Haghi, 2017). He stressed that rationality is the only way to guide science. Thus, the view of the concept of human personality described above will be an exciting difference between revelation and reason, and this is in line with Chittick's statement that western civilization has a sharp contrast in understanding science between the dogmas of revelation with rationality or reason. (Chittick, 2016).

In this case, more specifically, the researcher will be objective about the views about the concept of the human personality of these two figures. Therefore, this study needs to provide a complete picture based on a comparative analysis between Al-Ghazali and Sigmund Freud, which will later become an integrative conclusion between the two. Besides, the counseling perspective has a role in providing a personality description that needs attention in counseling. This will be the contribution of personality according to two figures in the science of counseling,

So, the counseling perspective in this study has the concept that is, personality is formulated from two figures of Al-Ghazali and Sigmund Freud when it has comprehensive suitability and contributes to personality theory for counseling that makes justification when it will provide the counseling process, then as a more general picture, according to Sigmund Freud's personality concept is better known or already has a real contribution to the birth of psychoanalysis, but on the other hand, the concept of human personality Al-Ghazali does not yet have a methodological study that can strengthen the development of theories about humans in general that have been described by Al-Ghazali in various his work. Herein lies the perspective of counseling in looking at humans more specifically to Al-Ghazali's personality theory, which requires research in academic terms with various works about humans that are still implied so that it becomes a contribution to the science of counseling as one of the applied sciences that has very significant developments. Therefore researchers want to analyze the concept of human personality according to Al-Ghazali, and Sigmund Freud reviewed from a counseling perspective as well as the differences and similarities in the concept of human personality, according to Al-Ghazali and Sigmund Freud.

\section{Methods}

The design of this study is an analytic design aimed at testing hypotheses and carrying out a more in-depth interpretation of a relationship of conformity in content and data. Ideally, the analysis design has been done before data collection begins. If the design in formulating a hypothesis is right, then the design of the analysis in parallel can be developed from the analysis of formulating the hypothesis. Hypotheses are the starting point of analysis, but imaginative thoughts and original thoughts will appear in the analysis and be adjusted to the available data. Furthermore, researchers will match hypotheses with data, adding less, reducing more. In this study, the hypothesis is divided into two. In general, namely the concept of relationships and the differences between the two theories of human personality according to the two figures. The comparison scheme can be seen in figure 1. 
Figure 1. Skeleton scheme of thinking comparative models

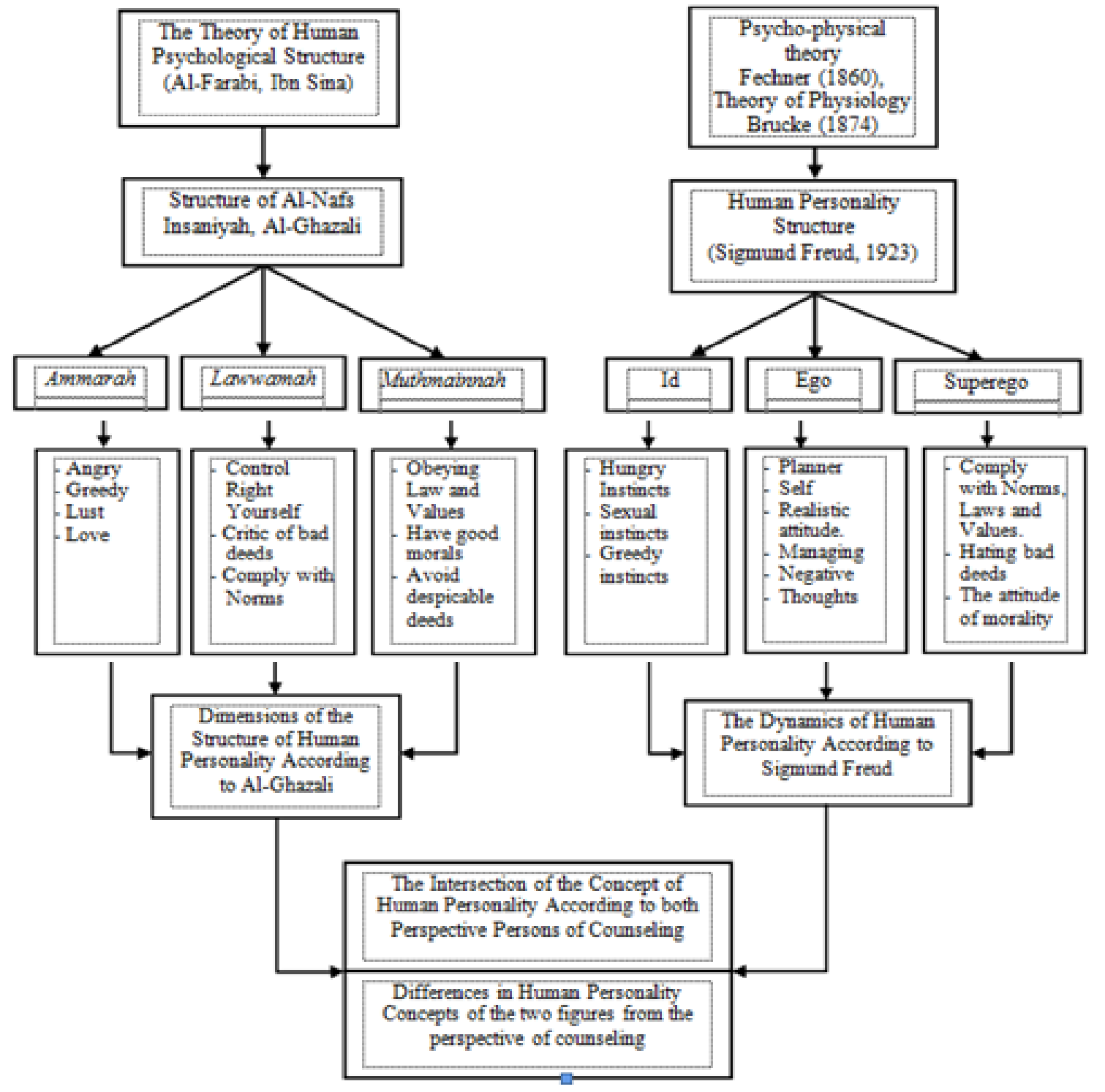

\section{Results and Discussion}

1. The concept of human personality according to the perspective of Al-Ghazali and Sigmund Freud.

A careful study of personalities built in the philosophy of Al-Ghazali and Freud revealed two types of thought. The first type of view represented by Al-Ghazali, who put more theological and less attention to rational human elements. The second type of thinking is described by Sigmund Freud, who underlines the rational elements of humanity, but confronts the aspects of the (revelatory) elements. Al-Ghazali takes the basis of his observations of human personality with the content of the revelation of Allah (al-Qur'an) and sets aside some of the signs in the announcement itself, which more or less also puts the same emphasis on the element rational or intellectual human factors. While Freud, although his methodology is rational, is still profoundly related to the concept of a belief (socio-religious) in reinforcing theories about his human personality.

This research shows that the two figures use a different methodological approach. This is perhaps the most striking difference between the philosophy of Al-Ghazali and Sigmund Freud. To distinguish between these conflicting points of view, the researcher would call the Al-Ghazali approach "theological" and Freud's "analytical" approach. They do not call their methodology this terminology. Still, from the careful study by the way they 
explain their thought ideas, researchers can conclude further observations in such a way that it will allow us to classify their approaches into two different methods.

First, the researcher intends Al-Ghazali's theological method is an analytical tool that emphasizes the prominent "exceptions" in the law that have been revealed and are the basis of specific requirements, which can be done in any type of discourse. So theological method is a procedure that is carried out by making the basis of revelation as a necessary measure in making consideration in thinking. Second, Freud's analysis method is a tool that analyzes several functions of the subject matter and separates from each other. In the Freudian perspective, this method is used to critically analyze the functions, roles, and limits of our ratios by developing a transparent, systematic network of mechanisms of our consciousness philosophically.

In this stage, Al-Ghazali states that humans to choose good deeds from bad ones to require al-ta'yid (reinforcement) from God, which is part of 'Inayat and taklif from God relating to human actions. Ayat Inayat God is the maintenance of everything that is in the best condition by His knowledge. Al-Ghazali argues, support is not only general but also is specific; God directs everyone in their actions that he saw that maintenance based on 'Inayat with human activities in the form of ta'yid (Parrott, 2017). Acts in their form are particular. The Dimension of Revelation is dominant in the role of Al-Ghazali so that his thoughts about the interpretation of ammarah as the nature or actions of humans who have the will for his actions. However, each behavior will still be a strength for each of each in every human being. That way, al-iradat and al-qudrat that exist in humans even though it is the forces that remain in humans are the will of God that has been outlined, humans will only live it.

Freud, who was born with the environment of Western philosophy, Greece, of course, uses the ratio as a starting point when going to find something. Freud's analytical approach indeed uses a more strategy to the concept in which he made himself the object of his research. By taking from terms such as the Greek mythology "Oedipus Kompleks" as having an essential role in the formation of the "psychological structure" of humans. In analytical methods, Freud wants to maintain how our ratio works. By separating between dogma and knowledge, broadly, Freud maintained his rationality as a scientist who demanded that he think scientifically.

In looking at human personality, Al-Ghazali is inseparable from revelation or theological sources (Shuhari et al., 2019). Revelation is the initial foundation of Al-Ghazali in giving meaning to something, including human personality. This can be seen from the division of human nafs (self) by referring to al-Qur'an by making the terms al-nafs alammarah, al-nafs, al-lawwamah, and al-nafs al-muthmainnah as representations of three forces or levels of human personality. The first level is called Al-Ghazali, as the lowest level of human self condition. The condition in Al-Ghazali's view is the result of Satan's temptations and changing people to do evil. One of the reinforcement propositions used in classifying nafs al ammarah is, Surat Yusuf: 51-53(Akhir \& Ibrahim, 2019). Human personality, according to Al-Ghazali nafs ammarah is a primary impetus for humans to fulfill what they want. This impulse in Al-Ghazali's philosophy can be said to have been embedded in every human nafs when it has been blown in the womb, clearly describing the story of human life. When humans do bad things, according to Al-Ghazali, it's because of the description of necessary human attitudes.

In characterizing human personality at the second level, Al-Ghazali uses the nafs lawwamah as an appropriate term in describing the human soul. This is a representation of human attitudes in their lives. The current nafs becomes Lawwamah as a human self, which ranges from a tendency to ugliness and also regrets when it has taken action. Nafs lawwamah as its basis, the proposition of Al-Ghazali put it in (Qur'an 75: 2), which means: "And I swear by the soul (nafs) who is very sorry (himself)." So, the self in this lawwamah nafs is the state 
of the human person which is still in an unstable state, but efforts to oppose evil deeds already exist in the state of the nafs (Abbazi \& Zarqan, 2019).

The third dimension in the human soul, according to Al-Ghazali, is the dimension, which is the highest state of the nafs. Al-Ghazali mentions that al-nafs al-muthmainnah as a soul that is protected from doubt and evil deeds (Asmaya, 2018). In this situation, the human soul can regulate impulses that lead to evil deeds. A peaceful soul is known in this dimension. Al-Ghazali made a proposition in the letter Ar-Rad [13]: 28 as an argument in determining the typology of human personality or nafs. This is consistent with the dogmatic ratio used by Al-Ghazali in seeing meaning in understanding the nature of human creation. This third dimension, as a representation of the state of one's nafs that can make it control the drive of evil, and be able to see the ability or strength of greater good deeds. Al-Ghazali made the basis of the will to create a better human personality with good pleasure. The pleasure that arises is the happiness that occurs, which envelops people. The attitude in the nafs muthmainnah can obey the laws, norms, and values contained in the sociological aspects. That value is included in God's revelation, as a form of personality (self) from the reflection contained in the Qur'an.

The above is the personality dimension, according to Al-Ghazali, and how to know the source of reasoning or dogmatic ratios used by Al-Ghazali in explaining how the classification of human personality is the primary source in this study. Furthermore, researchers will try to explain how Freud, taking the cause of his personality structure theory, namely the id, ego, and superego as critical analysis in the contents of this study. According to him, the three personality systems are interrelated and form a totality. The development of these three elements, according to Freud in individuals, varies considerably. For some people, the superego did not develop after childhood; for some people, the superego can master personality until people feel guilty and inferior. For others, ego and superego alternately control personality, which causes mood swings and alternating cycles of self-confidence and self-humiliation. In healthy people, the id, ego, and superego are well integrated and operate harmoniously with little conflict.

The essential personality, according to psychoanalysis in the psychic field, is called Id. Freud characterizes the id as "a crater full of boiling impulses," which contains the organic process energy of instincts and striving towards a goal: satisfaction of desires. The id is considered as the primary source of physiological energy which is revealed in the impulses of life and impulses to die (Becker, 2017). The id continues to demand an aggressiveness channel that seeks pleasure and might be called "animals in humans." The id operates entirely in the subconscious and is not regulated by considerations of time, logic, and place. The id contains everything psychologically inherited from birth. The id is the primary source of spiritual energy and a gathering place for instincts. In Freud's view, the id does not change with time; it cannot be altered by experience, because it has nothing to do with the outside world. However, the id can be controlled and monitored by the ego. Freud acknowledged that the id is a hidden and inaccessible part of the personality and that a little known about it was obtained as an investigation of dreams and symptoms of neurological disease.

The second in Freud's personality structure is ego. The ego is formed from a spiritual system, which is a reciprocal system between a person and the outside world that requires a religious network. In a person of calm character, the ego is the executor of personality, which controls and regulates the id and the superego and maintains with the outside world for the benefit of all figures and broad needs. One study revealed that if the ego does it wisely, there will be harmony (O'Neil, 2018). If the ego gives up on the id, the superego will be distorted and chaotic. In Freud's view, the ego plays a significant role in the survival of the other two systems. The ego is present as part of an organized id and to advance the purpose of the id, not to disappoint and all its strength from the id. Its primary role is to mediate the organism's 
inherent needs and the needs of the surrounding environment. A fundamental goal is to preserve the lives of individuals. Furthermore, age becomes a measure of psychological maturity that will help the ego control the id entirely. Freud was formulated with the egobased on his observations of the changes that occur in each phase of human life. In line with other studies that say ego means to control, that can regulate human psychic energy, prioritize gratification of desires or prioritize ideals that result in attitudes that are less favorable for each individual (Prem, Kubicek, Diestel, \& Korunka, 2016). The concept of ego offered by Freud is like mapping the human personality that every desire for fulfillment in a person has an activator who can refer to good deeds. This is where the ego emerges as a result of observing and analyzing the ratios, which are the basis of Freud's thought.

The concept of morality that arises from the creation of a social-community order encourages the emergence of the superego as a representation of the need for values contained in a society that is always in contact with what is called human. Superego is the embodiment of the moral and ethical part of the personality. The concept of the superego in Freud's eyes is the result of education in every individual's environment. A child will observe the behavior of parents and the environment that raises it. A person's life becomes complex when it collides with the norms and values that exist in society. This is what makes and strengthens the superego in its developmental stage. This means that as a third term in Freud's personality structure, the superego can be called the social aspect that shapes personality.

2. Comparison of the Personality Concepts of Al-Ghazali and Sigmund Freud

Comparison of the concept of personality between the two figures in this study, AlGhazali and Sigmund Freud, presented their understanding of human personality through a scheme called the structure of human personality. Philosophically, the explanation of the human personality proposed by Freud is based on rationality. On the other hand, Al-Ghazali has the perspective of a human personality born of "closeness and love for God" as the most significant concern in his way of thinking. This should be used as a starting point when you want to know the idea of personality. Revelation is the primary basis for Al-Ghazali in shaping and providing his understanding of human personality. While the ratio is the primary tool used by Freud in formulating human personality, this will be the beginning of the discussion about the meeting point of two personality concepts.

a. Similarities between the Personality Concepts of Al-Ghazali and Sigmund Freud

The concept of human personality in Al-Ghazali's view can be said to be essential and complete. Al-Ghazali noted that humans have a primary identity, which is, therefore, something that has the characteristics of making humans different from other creatures. Human personality is fixed and unchanging, standing alone and not housed, namely al-nafs (self). In the thought of Al-Ghazali derived from "revelation," the dimensions of al-nafs are divided into three, namely, al-nafs al-ammarah, al-nafs al-lawwamah, and al-nafs almuthmainnah. The first dimension attached to the gratification of desires and desires is alnafs al-ammarah (self which invites ugliness). Al-Ghazali provides an explanation when humans are confined in the first dimension of the nafs, which will become like an "animal," which only strengthens it because this mental state will only make humans order evil.

Meanwhile, Sigmund Freud also division (personality structure) is explained as a first psychic field and the first, namely id. Etymologically the idea of id can be attached to al-nafs al-ammarah mentioned by Al-Ghazali above because id is a part of human personality that only increases the desires and satisfaction of the "animal" instincts that exist in every human being. For example, researchers will give a similar picture between two terms, namely, when humans commit crime or murder, rape, and other harmful activities, the views of AL-Ghazali are carried out because they are influenced and are in al-nafs al. Ammarah even welcomed ID's explanation, according to Freud, "humans who commit crimes are under the influence of IDs," which cannot be controlled. That means the first mapping made by Al-Ghazali with 
dogmatic reasoning and Sigmund Freud with a speculative ratio found a meeting point in looking at evil humans by providing almost the same explanation, namely Al-Ghazali with alnafs al-ammarah and Freud with id.

The next term of two figures, namely Al-Ghazali with al-nafs al-lawwamah and Freud with ego. Al-Ghazali provides an understanding of al-nafs al-lawwamah taken from the source of "revelation," which explains that the component of Al-nafs al-lawwamah is tasked with compromising the drive for self-gratification of norms and at the same time as opposed to that. Because he (nafs) will fight the attitude of its owner, especially when he (the servant) fails to worship his Rabb, rejection of bad manners is a representation of the lawwamah nafs. However, at this stage, the characteristics of an individual's attitude can still make him trapped in the previous nafs when he cannot control himself. This is known as lawwamah is "a very sorry soul (himself).

Then, Freud also defines the ego as a term that becomes a shield from the strengthening of instincts and desires that arise from the id. A similarity that can be explained by the ego and nafs lawwamah as a defense for the hope that appears to do evil and the gratification of contrary desires in humans. This becomes clear when the researcher sees the framework of this research, which explains that the ego has a role that is almost the same as the nafs lawwamah.

Then the third term is al-nafs al-muthmainnah and superego. The concept of al-nafs al-muthmainnah is the dimension of personality that sets the values and norms that exist in every life of society. Freud's view of the superego is the moral or ethical part of the figure. Superego is the implication of social and moral norms. Previously, Al-Ghazali explained the nafs al-muthmainnah as an ideal form possessed by every human being, this is what can be connected with the superego, in this term the human personality has a concern that can explain the things that are right and wrong to act according to norms moral norms in society. This makes the human figure can run life by those in power and have a concept of a peaceful soul. This means that there is a third term relationship between the two figures, namely at the level of value and the implications made. Muthmainnah nafs as an implication of social value also with the superego.

b. Difference between the Concepts of Personality Al-Ghazali and Sigmund Freud

The highest aim of the concept of Al-Ghazali's human personality is his emphasis on "life after death." Whereas Sigmund Freud's focus was on "present life." This can be seen from the three essential components triggered by Al-Ghazali who prioritize the aspects of revelation, rather than reasoning. However, Freud's view, that the dogma contained in belief will only lead to uncertainty. Besides, Al-Ghazali's thought about human nafs (self) originating from revelation gives an understanding that human nafs has a level that can be had by every human at that level. The way it works is by categorizing human actions, good or bad. Then, the nafs lawwamah as a manifestation of the existence of human attitudes that are classified as rejecting evil deeds but sometimes can still enter the shackles of acts that are prohibited by religion. So that the limits of prohibitions and religious norms that exist in society become a way of thinking of someone who is in this nafs.

Then, the nafs muthmainnah as a representation of a human personality that has an attitude of peace and does not think more about the hope of salvation for life afterlife in the world, the hereafter. These, in turn, are formed through religious education taught from the start. That is, human existence at the level of the nafs described above can have the potential for evil or good or perhaps in its midst. This is what distinguishes the three-dimensional understanding of Al-Ghazali's nafs, which emphasizes the level of the nafs not as a reciprocal relationship or the meaning of its connection. Still, the human potential to enter into these three dimensions is something that can be used to strengthen this argument. 
Whereas in Freud's view of the structure of his human personality, he is like making a scheme that is interrelated between the id, the ego, and the superego. As a description of the three systems, it must be remembered that the three personality structures, according to Freud, are active and depend on each term. The point is that a person with a secure id and a weak ego has a superego very weak so that he is unable to keep up with the endless demands of the id. In line with research that says people with feelings of guilt or feelings of muscular inferiority and weak egos will experience conflict because the ego cannot make decisions about intense demands, but oppose the superego and the id (Warsah, 2018). Reinforced by other researchers who say someone with an ego who has included many id demands and almost all superego demands are psychologically healthy people, those who can control well the principles of pleasure and moralistic principles (Nagy, 2019).

So far, researchers can conclude that Freud's personality structure focuses on the ego, which has a vital role, namely as a control of the level of badness, id, and goodness that affects the perfection of the superego. That is, they work together like an ego-driven team. The personality in Freud's view is a single entity, not three separate systems. The id is assumed to be a biological component, ego as a psychological component, and superego the sociological element of personality. The contribution in this research is that the structure of human personality and psychoanalysis are important buildings as a necessary foundation for scientific counseling. In the conventional counseling stage, adopting psychoanalytic theory is a must. This is a contradiction in the beginning when the counseling process that has been established with the "old" theory is contrary to Al-Ghazali's theory, which is old. However, for the praxis or strategy stage, it is still foreign to apply.

This is the researcher's emphasis that needs to be incorporated into counseling knowledge is the theory of Al-Ghazali's nafs dimensions: ammarah nafs, lawwamah nafs, and muthmainnah nafs. Because the initial stage that can be done in this case is to provide productive arguments through research aimed at building a worldview in Islamic counseling, which is the initial foundation, namely, paradigm and epistemology, this means that the three nafs described by Al-Ghazali have continuity with the counseling process.

Al-Ghazali uses "revelation" to form the basis for formulating human personality. And, of course, Al-Ghazali provides a clear picture that the dimensions of the nafs ammarah, for example, by detecting the symptoms and characteristics of the nafs, can be used as a reference in giving and explaining "revelations" and limits that lead to judgment. By God in the hereafter. When used in counseling, with explanations reaching academic level, it triggers the birth of a generation of Islamic counselors who are more promising to solve problems that are not only temporary (world) but oriented to eternal (afterlife). As for Freud, the explanation of the structure of the human personality comes from analytic ratios derived from his research on himself or others as his subjects. Elsewhere, Al-Ghazali has far given a picture of the dimension of the nafs, which is based on "revelation," which forms the basis for Al-Ghazali that truth is religion or monotheism. It can be adopted that the counseling process should not only alleviate practical problems but also can guarantee the next life, that is, the hereafter.

\section{Conclusions and Suggestions}

Several things can be drawn to the conclusion. Namely, the concept of human personality, according to Al-Ghazali, is divided into three dimensions, namely, nafs alammarah, nafs al-lawwamah, and nafs muthmainnah have a meeting point or relationship with the concept of personality structure according to Sigmund Freud, that is, id, ego, and superego. The relationship is, with meaning and value (normative), etymologically, axiology, which in time will become a sturdy epistemological building for the development of the concept of human personality, according to Al-Ghazali more specifically. The difference in 
human concepts, according to Al-Ghazali and Sigmund Freud, lies in the workings of the three terms of human personality.

Al-Ghazali explained that the dimension of the nafs is the level that has the potential that every human being will be in it. Whereas the concept of the structure of the human personality that has been explained according to Freud, namely, the three systems are interrelated and controlled by the ego as a controller to decide human behavior and personality. The concept of Al-Ghazali's human personality, with its nafs dimension, becomes a pressure point in the contribution of counseling, especially in building the Islamic counseling paradigm. The typology of the nafs, according to Al-Ghazali, which in its normative explanation, can be aligned with the structure of Freud's human personality. For example, using the proposition "revelation" as the basis of Al-Ghazali's thinking can be more reinforcing in the counseling process. With the counseling process strengthened by the proposition, "revelation" will be the alleviation of more complex problems, get a place to be freer from the shackles of world problems, and get peace, answers to life in the afterlife. The next researcher is suggested to implement the Islamic counseling process with a focus on personality dimensions according to Al-Ghazali.

\section{References}

Abbazi, U., \& Zarqan, I. A. (2019). Islamic pedagogy on human resource management based on islamic references. Jiber: Journal of Islamic Business and Economic Review, 2(1), $34-42$.

Akhir, N. S. M., \& Ibrahim, N. (2019). Analysis of violent act from the islamic spiritual perspective. International Journal Of Academic Research In Business And Social Sciences, 9(3).

Asmaya, E. (2018). Hakikat manusia dalam tasawuf al-ghazali. Komunika: Jurnal Dakwah Dan Komunikasi, 12(1), 123-135.

Becker, B. (2017). Flight from the flesh: Freud's id and ego as saturated phenomena. Breached Horizons: The Philosophy of Jean-Luc Marion, 252.

Booth, A. R. (2017). The philosophers strike back: Averroes and islamic philosophy after alGhazali. In Analytic Islamic Philosophy (pp. 143-169). Springer.

Campanini, M. (2018). Al-Ghazali and the Divine. Routledge.

Chittick, W. C. (2016). Ibn al- 'Arabī. Journal of the Muhyiddin Ibn'Arabi Society, 59.

Haghi, A. (2017). God and man in Freudian psychoanalysis: a critical examination of Freud's the future of an illusion. Religious Inquiries, 6(12), 41-55.

Imdad, M., Hafidhuddin, D., \& Arif, S. (2019). Defining education: al-Farabi and Ibn Sina terminologies. Ibn Khaldun Journal of Social Science, 1(1), 1-10.

Jones, E. (2019). The life and work of Sigmund Freud. Plunkett Lake Press.

Mandelbaum, M. (2019). History, man, and reason: A study in nineteenth-century thought. JHU Press.

Međedović, J. (2018). What can human personality psychology learn from behavioral ecology. Journal of Comparative Psychology, 132(4), 382.

Nagy, C. I. (2019). Major European objections and fears against the opt-out system: superego, ego and id. In Collective Actions in Europe (pp. 23-44). Springer.

Niaz, A., Stanikzai, S. M., \& Sahibzada, J. (2019). Review of Freud's psychoanalysis 
approach to literary studies. American International Journal of Social Science Research, $4(2), 35-44$.

O’Neil, J. A. (2018). Hypnosis and psychoanalysis: Toward undoing Freud's primal category mistake. American Journal of Clinical Hypnosis, 60(3), 262-278.

Parrott, J. (2017). Al-Ghazali and the golden rule: Ethics of reciprocity in the works of a Muslim sage. Journal of Religious \& Theological Information, 16(2), 68-78.

Prem, R., Kubicek, B., Diestel, S., \& Korunka, C. (2016). Regulatory job stressors and their within-person relationships with ego depletion: The roles of state anxiety, self-control effort, and job autonomy. Journal of Vocational Behavior, 92, 22-32.

Shuhari, M. H., Hamat, M. F., al-Shafi, M. M. O., Jusoh, W. H. W., Zin, S. A. M., \& Wahab, M. R. (2019). The concept of integrity for Muslim's character based on Al-Ghazali's ethical perspective. Journal of Legal, Ethical and Regulatory Issues.

Starkstein, S. (2018). Sigmund Freud and the psychoanalytical concept of fear and anxiety. In A Conceptual and Therapeutic Analysis of Fear (pp. 231-257). Springer.

Valsiner, J., Chaudhary, N., \& Benetka, G. (2017). From methodology to methods in human psychology. Springer.

Warsah, I. (2018). Interkoneksi pemikiran Al-Ghazāli dan Sigmund Freud tentang potensi manusia. Kontekstualita, 32(01).

Yahya, N., Omar, S. H. S., Al-Shafi, M. M. O., Abdullah, M. S., Ali, M. S., Engku, E. I., \& Zin, W. (2018). The concept of human will according to Al-Ghazali and Abraham Maslow: A Comparative Study. International Journal Of Academic Research In Business And Social Sciences, 8(10), 91-99. 
